\title{
Chemical study of vermicomposted agroindustrial wastes
}

\author{
Lívia B. Favoretto Pigatin ${ }^{1}$ (1) Idowu Ademola Atoloye ${ }^{2} \cdot$ Oluwatoyin Abosede Obikoya $^{3}$. \\ Aurélio Vinicius Borsato ${ }^{4} \cdot$ Maria Olímpia Oliveira Rezende ${ }^{1}$
}

Received: 8 March 2015/ Accepted: 13 January 2016/Published online: 8 February 2016

(c) The Author(s) 2016. This article is published with open access at Springerlink.com

\begin{abstract}
Purpose The disposal of solid waste is a serious environmental problem for humanity. Vermicomposting is used as one of the methods for recycling of organic waste, resulting in a humified material of great agronomic potential which promotes carbon sequestration when applied to the soil. The aim of this study was to evaluate the chemical characteristics of vermicomposts from cattle manure (CM), orange peel (OP) and filter cake (FC).

Methods Three compost piles were set up, 2:1 OP + CM, 3:1 FC + CM and CM. The piles were initially composted for 60 days. Thereafter, earthworms were added to the piles to initiate the vermicomposting process.
\end{abstract}

Lívia B. Favoretto Pigatin

liviafavoretto@yahoo.com.br

Idowu Ademola Atoloye

iatoloye@oauife.edu.ng

Oluwatoyin Abosede Obikoya

maritobee@yahoo.com

Aurélio Vinicius Borsato

aurelio.borsato@embrapa.br

Maria Olímpia Oliveira Rezende

mrezende@iqsc.usp.br

1 Environmental Chemistry Laboratory-São Carlos Chemistry Institute, University of São Paulo, 400 Trabalhador Sãocarlense Av, São Carlos, SP 13566-590, Brazil

2 Department of Soil Science and Land Resources Management, Faculty of Agriculture, Obafemi Awolowo University, Ile-Ife, Nigeria

3 Department of Soil Science, Faculty of Agriculture and Food Science, University of Manitoba, Winnipeg, MB R3T 2N2, Canada

4 Embrapa Pantanal, 118021 de Setembro St, Corumbá, MS 79320-900, Brazil
Results The $\mathrm{pH}$ and the organic carbon contents were above the minimum recommended values for organic fertilizers. The $\mathrm{N}$ content was below the minimum value but the $\mathrm{C} / \mathrm{N}$ ratio was in the required range. The $\mathrm{C} / \mathrm{N}$ values where lower in $\mathrm{OP}+\mathrm{CM}$ and $\mathrm{FC}+\mathrm{CM}$ than in $\mathrm{CM}$. Further, the $\mathrm{N}$ contents of treatments were different with $\mathrm{OP}+\mathrm{CM}$ having the highest value. The $\mathrm{C} / \mathrm{N}$ ratios of the piles were 9.52, 9.62 and 11.03 for $\mathrm{OP}+\mathrm{CM}, \mathrm{FC}+\mathrm{CM}$ and $\mathrm{CM}$, respectively, and were lower than the maximum recommended value by the Ministry of Agriculture, Livestock and Food (Ministry of Agriculture 2009).

Conclusion Thus, co-vermicomposting of filter cake and orange peel with cattle manure has the potential for application sustainable agriculture.

Keywords Vermicompost - Organic matter - Orange peel waste $\cdot$ Filter cake waste $\cdot$ Cattle manure

\section{Introduction}

Increase in agricultural production appears to be a major threat to soil sustainability. This is due to increasing demand for food by the increasing human population. There is a need to sustain the physical, chemical and biological properties of the soil if more food is to be produced. The use of inorganic fertilizers only supplies plant nutrients and cannot improve soil quality. Rather, it promotes soil degradation and environmental pollution. However, the use of organic fertilizers had been shown to be a good means of improving soil quality and promoting sustainable agriculture (Rezende et al. 2014).

Enormous amounts of wastes generated from agricultural activities are a vast sources of plant nutrients, including macro- and micro-nutrients in organic forms. The 
inappropriate disposal of agro-wastes can lead to environmental problems and affect human health. However, these wastes are resources that could be of immense benefit to agriculture and the environment if properly harnessed (Rodella and Alcarde 1994). Vermicomposting has been adjudged superior to composting due to its ability to reduce the concentration of toxic elements contained in organic wastes (Rezende et al. 2014). Vermicomposting involves the transformation of organic matter (OM) into stable form through the action of earthworms and microorganisms living in their gut (Juárez et al. 2011). It is considered a most economical and high technology-free practise for onsite waste processing (Suthar 2012). Earthworms increase aeration and promote fast decomposition of organic substances during this process. Physical and chemical parameters such as $\mathrm{pH}$, temperature, aeration, moisture content, $\mathrm{OM}$ and $\mathrm{C} / \mathrm{N}$ ratio govern the development of the vermicomposting process (Pramanik et al. 2007; Juárez et al. 2011; Suthar 2012). The life cycle of the earthworms is regulated by these parameters. Adult worms require 60-80\% moisture content, optimal temperature of 15-25 ${ }^{\circ} \mathrm{C}$ and $\mathrm{pH}$ 6.8-7.8 for development (Juárez et al. 2011). The recommended specifications for organic fertilizers in Brazil are minimum values of $5 \%$ of total N, $10 \%$ organic $\mathrm{C}$, minimum $\mathrm{pH}$ of 6.0 , maximum $\mathrm{C} / \mathrm{N}$ ratio of 14 (Brazil 2009).

The central administrative region of São Paulo state, in which lies the city of São Carlos, is characterized by intense agro pastoral activity, especially livestock feedlot and extensive cattle rearing. There is also intense sugar cane production, in addition to traditional orange production. These activities generate organic wastes that could be used as feedstock for vermicomposting, obtaining final products with different chemical characteristics and fertility. Thus, due to the wide availability, low cost, and the possibility of proposing a more environmentally viable alternative to some wastes generated in the region of São Carlos, the following organic residues were studied: orange peel, filter cake and cattle manure. Orange peel (citrus processing industry) and filter cake (from sugar and ethanol industrial residue obtained during the process of production of sugarcane juice) were used for this study due to their high availability as byproducts in São Paulo state, Brazil. Orange peel has $23 \%$ crude protein, $3 \%$ lignin, high content of pectin and soluble carbohydrate content ranging around $37.1-43.2 \%$ of dry matter (Itavo et al. 2000). The filter cake had mineral impurities and the pulp of the sugarcane particles retained in sieves during the juice filtration. The main nutrients found in filter cake were: $\mathrm{P}\left(13.5-26.1 \mathrm{~g} \mathrm{~kg}^{-1}\right)$ in the form of $\mathrm{P}_{2} \mathrm{O}_{5}$ followed by $\mathrm{Ca}\left(21.0-50.4 \mathrm{~g} \mathrm{~kg}^{-1}\right)$ and $\mathrm{C}\left(8.7-14.1 \mathrm{~g} \mathrm{~kg}^{-1}\right)$ (Morelli 2004).

It is necessary to evaluate specific characteristics of the residues to be vermicomposted, such as $\mathrm{C}$, total $\mathrm{N}, \mathrm{P}$ and macro- and micro-nutrient contents to understand the ability of the so produced vermicompost to supply nutrients to plant and not contaminate the environment. Thus, the aim of this work was to evaluate the chemical transformations of agricultural wastes during vermicomposting to apply the so produced vermicomposts to the soil for the maintenance of soil organic matter (SOM).

\section{Materials and methods}

\section{Vermicomposting}

The experiment was conducted on an outdoor concrete platform on a farm located in the region of São Carlos, São Paulo state, Brazil. The experiment was initiated in September 2011 and lasted for 6 months. In natura, residues were dried at room temperature and ground in a knife mill. The piles were $2.25 \mathrm{~m}^{3}$ with dimensions of $1.5 \mathrm{~m}$ length $\times 1.5 \mathrm{~m}$ width $\times 1 \mathrm{~m}$ height. The treatments were orange peel $(\mathrm{OP})+$ cattle manure $(\mathrm{CM})$ in the ratio of $2: 1$ $(\mathrm{OP}+\mathrm{CM})$, filter cake $(\mathrm{FC})+$ cattle manure in the ratio 3:1 $(\mathrm{FC}+\mathrm{CM})$ and cattle manure only $(\mathrm{CM})$ by dry weight. Three piles were prepared in triplicate using different organic residues with the following wet weights: Pile 1,2 and 3 (P1, P2, P3): $300 \mathrm{~kg}$ of orange peel $+150 \mathrm{~kg}$ of fresh cattle manure; Pile 4, 5 and 6 (P4, P5, P6): $450 \mathrm{~kg}$ of filter cake $+150 \mathrm{~kg}$ of fresh cattle manure; Pile 7, 8 and 9 (P7, P8, P9): $400 \mathrm{~kg}$ of cattle manure (used as reference of slow composting process). Sawdust was used as structuring agents and to assist in the aeration of the piles. The proportions of mixed waste with cattle manure were determined according to the amount of material available and to obtain a $\mathrm{C} / \mathrm{N}$ ratio suitable for starting the composting process, around 20 and 30 for the piles. An adequate C:N ratio promotes the activity of the microorganisms in organic waste degradation process. A C:N ratio around 20-30 is considered appropriate for the beginning of the co-vermicomposting process, enabling the production of vermicompost in less time. At the end of the degradation process, the humified compost should have a $\mathrm{C}: \mathrm{N}$ ratio around 10:1. The piles were assembled layer by layer with each layer being approximately $20 \mathrm{~cm}$ in height independent of mass, in the following order: sawdust-cattle manure-orange peel or filter cake, repeatedly. Water was added to each layer, so that at the end the piles were moist. The mixtures were composted and their moisture contents adjusted to about $60 \%$ once a week during the composting process. The piles were manually turned each week until the 6th week. At the end of the 6th week, the composting process returned to mesophilic phase, as observed by temperature measurements, and then the organic composts were moved to boxes. Five hundred earthworms (Eisenia 
fetida) were added in each box. Young earthworms were used. Young worms are worms with no clitellum. When mature, a swollen area of the epidermis called clitellum, located in particular segments, forms a cocoon in which the eggs or ova are deposited, and are then passed over the anterior segment (Edwards and Bohlen 1996). The mass of each worm was about $10.0 \mathrm{~g}$ and the total mass was about $5.0 \mathrm{~kg}$ of earthworms per box. The contents in the boxes were manually turned every 15 days until the end of the process. Random samples were taken from within the piles and the outer layer at the start and at 7, 15, 30, 45, 60, 75, $90,105,120$ and 135 days after the beginning of the composting process. Each sample was a mixture of eight subsamples taken from different points along the pile. The samples were dried at $60{ }^{\circ} \mathrm{C}$, grounded and passed through a $0.5 \mathrm{~mm}$ sieve.

\section{Chemical characterization of the wastes}

The chemical properties of the wastes are presented in Table 1. These results were used for adjusting the $\mathrm{C} / \mathrm{N}$ ratios to the appropriate levels of around 20 and 30 for the vermicomposting process.

\section{Temperature measurements}

Temperature was taken daily at three different points (base, middle and top) between 6 and 7 a.m., by inserting a thermometer into the pile. The temperatures were monitored weekly until the sixth week of the composting process, then become constants.

\section{Chemical analyses}

To measure the $\mathrm{pH}$, samples were mixed together with of $0.01 \mathrm{~mol} \mathrm{~L}^{-1} \mathrm{CaCl}_{2}(1: 10, \mathrm{w} / \mathrm{v})$ and stirred for $30 \mathrm{~min}$. The $\mathrm{pH}$ was measured in the slurry using a Tecnal TEC-2 electronic $\mathrm{pH}$ meter combined with glass electrode. Total $\mathrm{C}, \mathrm{N}, \mathrm{H}$ and $\mathrm{S}$ contents of collected samples were determined using a CHNS-O analyser (CE Instruments EA1110). The determinations were made from an eluted mixture separated by chromatography column and detected by a detector in response to $\mathrm{N}_{2}, \mathrm{CO}_{2}, \mathrm{H}_{2} \mathrm{O}$ and $\mathrm{SO}_{2}$. The
$\mathrm{C} / \mathrm{N}$ ratios were calculated as the quotient of elemental concentration and atomic weight. The macronutrients $(\mathrm{N}, \mathrm{P}$ and $\mathrm{K}$ ) and micronutrients $(\mathrm{Fe}, \mathrm{Mn}, \mathrm{Cu}, \mathrm{Zn}, \mathrm{Cr}, \mathrm{Ca}$, and $\mathrm{Mg}$ ) were determined for samples collected at time zero and after 135 days of vermicomposting. Samples were digested using the microwave oven digester (BERGHOF Speed Wave Four). The determinations of $\mathrm{Fe}, \mathrm{Mn}, \mathrm{Cu}, \mathrm{Zn}$, $\mathrm{K}, \mathrm{Cr}, \mathrm{Ca}$ and $\mathrm{Mg}$ were made using Atomic Absorption Spectrophotometer. Total Kjeldahl nitrogen (TKN) and phosphorus were determined by $\mathrm{Hach}^{\circledR}$ method 399 and Hach $^{\circledR}$ method 480, respectively; and the cation exchange capacity (CEC), through the occupation of active sites to exchange with hydrogen ions in solution $1 \mathrm{~mol} \mathrm{~L}^{-1}$ of glacial acetic acid. All the determinations were performed in triplicates (Rezende et al. 2014).

\section{Statistical analysis}

Data generated from all analyses were subjected to analysis of variance (ANOVA) and pair wise comparison using Tukey test $(p<0.05)$. The SAS 9.0 Software Package program was used (SAS Institute 2004).

\section{Results and discussion}

\section{Temperature changes with vermicomposting}

During the vermicomposting, the temperature variation in all piles showed similar trends as observed during composting processes (Ros et al. 2006; Fialho et al. 2010). At the beginning of the first week, the temperature ranged from 25 to $30{ }^{\circ} \mathrm{C}$ which is the mesophilic phase. At the end of the second week, maximum temperatures of between 50 and $60{ }^{\circ} \mathrm{C}$ were recorded in piles $2: 1 \mathrm{OP}+\mathrm{CM}$ and 3:1 $\mathrm{FC}+\mathrm{OM}$ while in pile $\mathrm{CM}$, the maximum temperature was $40{ }^{\circ} \mathrm{C}$. The heat generated in composting thermophilic phase results in higher temperatures. After 60 days, the temperature decreased to about $25{ }^{\circ} \mathrm{C}$ in the cooling and maturation phase. According to Fialho et al. (2010) these changes in temperatures were the consequences of microbial degradation activities on the residues and also of the microbial population dynamics. The nature of composted
Table 1 Chemical properties of the organic wastes used for vermicomposting

\begin{tabular}{llll}
\hline Parameters & Orange peel $(\mathrm{OP})$ & Filter cake $(\mathrm{FC})$ & Cattle manure $(\mathrm{CM})$ \\
\hline $\mathrm{C}_{\text {total }}^{\mathrm{a}}$ & $41.95 \pm 5.28$ & $37.97 \pm 0.38$ & $32.11 \pm 4.32$ \\
$\mathrm{~N}_{\text {total }}^{\mathrm{a}}$ & $1.34 \pm 0.00$ & $1.73 \pm 0.00$ & $1.73 \pm 0.00$ \\
$\mathrm{C} / \mathrm{N}$ & 36.63 & 25.66 & 26.11 \\
$\mathrm{pH}^{\mathrm{b}}$ & $2.40 \pm 0.40$ & $7.30 \pm 0.00$ & $8.00 \pm 0.10$ \\
\hline
\end{tabular}

${ }^{\text {a }}$ Results expressed in \% of dry matter

b Measured in $\mathrm{CaCl}_{2} 0.01 \mathrm{~mol} \mathrm{~L}^{-1}(1: 10, \mathrm{w} / \mathrm{v})$ 
materials affected the maximum temperature attained (Ros et al. 2006). The initial increase in temperature of the composting pile was a result of the rapid breakdown of the readily available $\mathrm{OM}$ and nitrogenous compounds by microorganisms. The high temperatures $\left(40-60^{\circ} \mathrm{C}\right)$ ensured that $\mathrm{OM}$ was stabilised and that pathogenic microorganisms are suppressed. The rate of decomposition decreased as the OM became more stabilised thus signifying the end of the thermophilic phase also as indicated by Ros et al. (2006).

The maximum temperature reached in piles 2:1 $\mathrm{OP}+\mathrm{CM}$ and 3:1 FC $+\mathrm{CM}$ could be attributed to the increased microbial activity due to higher nutrient content than CM. According to Fialho et al. (2010), microbial growth and efficiency of composting process also depends on the type of substrate.

\section{The $\mathrm{pH}$ of the vermicomposts}

During the experiment, some variations in the $\mathrm{pH}$ were observed in the piles (Fig. 1). In the 2:1 OP + CM pile, there was a slight increase of $\mathrm{pH}$ from 7.09 to 8.26 , while in pile 3:1 FC + CM there was a slight decrease of $\mathrm{pH}$ (8.40-7.55) and in pile $\mathrm{CM}$, the $\mathrm{pH}$ was practically the same at the beginning and at the end of the process $(\sim 7.8)$. The $\mathrm{pH}$ values in the piles were near neutrality or slightly alkaline at the end of the process. This indicates expected conditions of stabilized compost. Forty-five days after the addition of earthworms, $\mathrm{pH}$ values tended to decrease 1 unit from basic to slightly basic or neutral. Bhat et al. (2015) also observed a decrease in $\mathrm{pH}$ during the vermicomposting process of mixtures of bagasse waste of the sugar industry and cattle dung. The authors explain that the decline in $\mathrm{pH}$ during vermicomposting is due to the mineralization of nitrogen and phosphorus compounds and the production of humic and fulvic acids.

It is noteworthy that pile $2: 1 \mathrm{OP}+\mathrm{CM}$ only achieved neutral $\mathrm{pH}$ values early in the process due to the addition of cattle manure, because the $\mathrm{pH}$ of pure orange peel was $2.5 \pm 0.4$ (Table 1). Furthermore, the first stage of vermicomposting process was the composting in piles, allowing a stabilization of the material before the addition of the earthworms.

\section{The $\mathrm{C}$ and $\mathrm{C} / \mathrm{N}$ ratio of the vermicomposts}

There was a decrease in the $\mathrm{C}$ contents in the three different treatments at the end of the process (Table 2). This was as a result of the mineralization of the organic matter (OM) by microorganisms. A decrease in $\mathrm{C}$ content had earlier being reported by Huang et al. (2006) during the composting of pig manure with sawdust. Bhat et al. (2015) also reported a decrease of organic carbon in all the end products of post-vermicomposting of mixtures of bagasse waste of the sugar industry and cattle dung. The $\mathrm{C}$ content in piles $\mathrm{CM}$ and 3:1 $\mathrm{FC}+\mathrm{CM}$ decreased by $58 \%$ while in pile $2: 1 \mathrm{OP}+\mathrm{CM}$ it reduced by $53 \%$. This could be due to the characteristics of the orange peel as it contains more lignin which is not easily degraded. The rates of mineralization of the OM decreased in the three piles at the end of 105 days as no further significant decreases were observed. Total $\mathrm{N}$ contents of the three piles at the beginning and at
Fig. 1 Changes in $\mathrm{pH}$ during the vermicomposting process

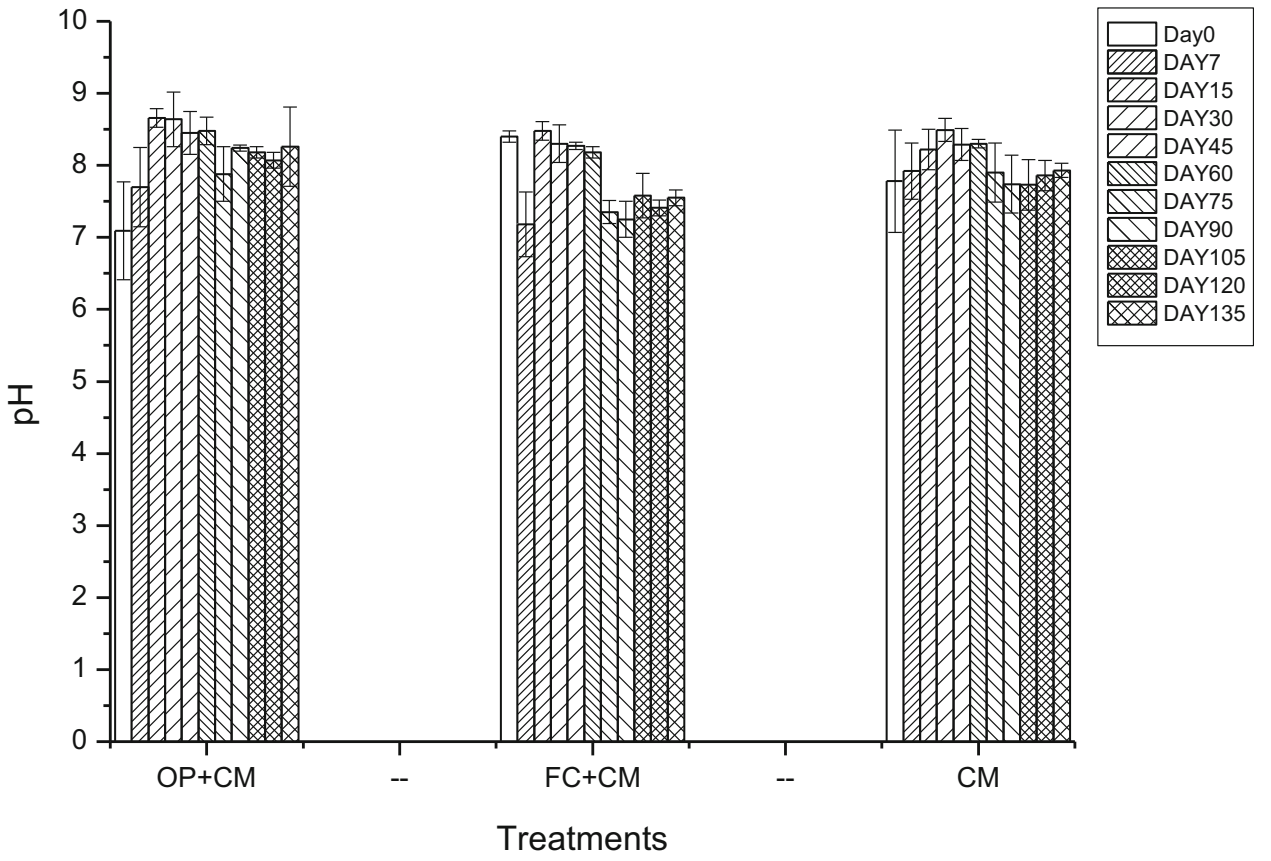


Table 2 Elemental analysis during the vermicomposting process

\begin{tabular}{|c|c|c|c|c|}
\hline Treatments & Time (days) & $\mathrm{N}(\%)$ & $\mathrm{C}(\%)$ & $\mathrm{H}(\%)$ \\
\hline \multirow[t]{11}{*}{$\mathrm{OP}+\mathrm{CM}$} & 0 & $1.57 \mathrm{e}$ & $34.75 \mathrm{a}$ & $4.90 \mathrm{a}$ \\
\hline & 7 & $2.62 \mathrm{e}$ & $33.02 \mathrm{ab}$ & $4.65 \mathrm{ab}$ \\
\hline & 15 & 2.01de & $34.28 \mathrm{a}$ & $4.60 \mathrm{ab}$ \\
\hline & 30 & $2.66 \mathrm{c}$ & $32.72 \mathrm{abc}$ & $4.19 \mathrm{abc}$ \\
\hline & 45 & $2.54 \mathrm{c}$ & 33.09ab & $4.29 \mathrm{ab}$ \\
\hline & 60 & $2.67 \mathrm{c}$ & $32.12 \mathrm{abc}$ & $4.35 \mathrm{ab}$ \\
\hline & 75 & $2.42 \mathrm{~cd}$ & $26.96 \mathrm{c}$ & $3.64 \mathrm{bc}$ \\
\hline & 90 & $3.97 \mathrm{a}$ & $27.71 b c$ & $5.06 \mathrm{a}$ \\
\hline & 105 & $3.37 \mathrm{~b}$ & $19.23 \mathrm{~d}$ & $4.18 \mathrm{abc}$ \\
\hline & 120 & $2.33 \mathrm{~cd}$ & $19.80 \mathrm{~d}$ & $3.29 b$ \\
\hline & 135 & 2.00de & $16.34 \mathrm{~d}$ & $2.37 \mathrm{~d}$ \\
\hline \multirow{11}{*}{$\mathrm{FC}+\mathrm{CM}$} & 0 & $2.71 \mathrm{~cd}$ & $27.12 \mathrm{abc}$ & $4.22 \mathrm{a}$ \\
\hline & 7 & $1.65 \mathrm{~cd}$ & $29.41 \mathrm{ab}$ & $4.12 \mathrm{a}$ \\
\hline & 15 & $2.17 \mathrm{c}$ & $30.57 \mathrm{a}$ & $4.39 \mathrm{a}$ \\
\hline & 30 & $2.24 b c$ & $28.13 \mathrm{ab}$ & $4.06 \mathrm{a}$ \\
\hline & 45 & $2.20 \mathrm{c}$ & $27.07 \mathrm{ab}$ & $3.99 \mathrm{a}$ \\
\hline & 60 & $2.13 \mathrm{c}$ & 26.77abc & $3.91 \mathrm{a}$ \\
\hline & 75 & $2.24 b c$ & $25.02 \mathrm{abc}$ & $3.69 \mathrm{a}$ \\
\hline & 90 & $3.24 \mathrm{a}$ & 20.56abcd & $4.45 \mathrm{a}$ \\
\hline & 105 & $2.95 \mathrm{ab}$ & $16.91 \mathrm{~cd}$ & $3.48 \mathrm{a}$ \\
\hline & 120 & $2.05 \mathrm{~cd}$ & $19.73 \mathrm{~cd}$ & $3.28 \mathrm{a}$ \\
\hline & 135 & $1.38 \mathrm{~d}$ & $11.36 \mathrm{~d}$ & $2.03 b$ \\
\hline \multirow[t]{11}{*}{$\mathrm{CM}$} & 0 & $1.50 \mathrm{c}$ & $29.63 \mathrm{ab}$ & $4.23 \mathrm{a}$ \\
\hline & 7 & $1.88 \mathrm{bc}$ & $33.76 \mathrm{c}$ & $4.72 \mathrm{a}$ \\
\hline & 15 & $1.82 \mathrm{bc}$ & $30.41 \mathrm{ab}$ & $4.21 \mathrm{a}$ \\
\hline & 30 & $1.84 \mathrm{bc}$ & 30.39ab & $4.13 \mathrm{a}$ \\
\hline & 45 & $1.77 \mathrm{bc}$ & $25.59 \mathrm{abc}$ & $3.57 \mathrm{a}$ \\
\hline & 60 & $1.89 \mathrm{bc}$ & $27.03 \mathrm{abc}$ & $3.77 \mathrm{a}$ \\
\hline & 75 & $1.61 b c$ & 21.78abcd & $3.04 \mathrm{a}$ \\
\hline & 90 & $2.99 a$ & $18.96 \mathrm{bcd}$ & $4.14 \mathrm{a}$ \\
\hline & 105 & $2.81 \mathrm{a}$ & $14.74 \mathrm{~cd}$ & $3.31 \mathrm{a}$ \\
\hline & 120 & $2.18 \mathrm{~b}$ & $24.61 \mathrm{abcd}$ & $3.70 \mathrm{a}$ \\
\hline & 135 & $1.31 \mathrm{c}$ & $12.43 d$ & $1.92 b$ \\
\hline
\end{tabular}

Values followed by the same letter within the same column are not significantly different at $p<0.05$ according to Tukey test

the end of the vermicomposting were not significantly different. At the end of 90 days, the total $\mathrm{N}$ in the three piles was of maxima having increased by 152, 19.5 and $99 \%$ in piles 2:1 OP $+\mathrm{CM}, 3: 1 \mathrm{FC}+\mathrm{CM}$ and $\mathrm{CM}$, respectively (Table 2). According to Bernal et al. (2009), the loss of $\mathrm{N}$ during composting occurs through volatilization of ammonium, thus making the total $\mathrm{N}$ to reduce at the end of the process. It is also possible for the nitrogen to have been lost through denitrification.

Figure 2 shows the $\mathrm{C} / \mathrm{N}$ ratio versus time for the three systems. The $\mathrm{C} / \mathrm{N}$ ratio is often used to assess the evolution of the degradation process (Huang et al. 2004). There was a rapid decrease in the $\mathrm{C} / \mathrm{N}$ ratio of the pile $2: 1 \mathrm{OP}+\mathrm{CM}$ from initial value of 25.96-14.36 after 30 days of composting, and this gradually continued to decrease to 6.65 at the end of 105 days. In pile 3:1 $\mathrm{FC}+\mathrm{CM}$, the $\mathrm{C} / \mathrm{N}$ ratio decreased gradually until a minimum of 6.62 at the end of 105 days while in pile $\mathrm{CM}$ the minimum $\mathrm{C} / \mathrm{N}$ ratio was 6.10 after 105 days. This was due to the continuous loss of $\mathrm{C}$ through microbial respiration during the process. This was similar to the report by Juárez et al. (2011). At the end of 90 days, the $\mathrm{C} / \mathrm{N}$ ratios of the three piles were less than 8.14. According to Bernal et al. (1998) a $\mathrm{C} / \mathrm{N}$ ratio less than 12 indicates the maturity of the compost and its suitability for addition to soils. It could be concluded that the compost reached maturation after 90 days. It has been suggested that the $\mathrm{C} / \mathrm{N}$ ratio index should be considered along with other parameters when monitoring compost stabilization (Fialho et al. 2010). These authors also observed that in some compost piles, although the $\mathrm{C} / \mathrm{N}$ had stabilized, the temperature range was still in the thermophilic phase, which is an indication that the composts were not yet stabilized at that time. The evolution of the process depends strongly on the nature of the material used in the compost and/or vermicompost and the $\mathrm{C} / \mathrm{N}$ ratio affects the rate at which the material is stabilized in terms of microbiological activity. Similar results were also observed by Bhat et al. (2015). At the end of the vermicomposting process, the $\mathrm{C} / \mathrm{N}$ ratios in the $\mathrm{OP}+\mathrm{CM}, \mathrm{FC}+\mathrm{CM}$ and $\mathrm{OM}$ piles were 9.51, 9.62 and 11.03, respectively. These values indicated lower microbial activity and the possible stabilization of the material as also suggested by Provenzano et al. (2001), Bernal et al. (1998) and Chefetz et al. (1996). The decrease in $\mathrm{C} / \mathrm{N}$ ratio as a function of vermicomposting time is indicative of increased humification of $\mathrm{OM}$, which is directly related to the quality and maturity of the vermicompost. The $\mathrm{C} / \mathrm{N}$ is also indicative of the degree of incorporation of $\mathrm{N}$ into the humic structure. Table 2 shows the increase of $\mathrm{N}$ content up to 120 days for vermicomposts from $\mathrm{FC}+\mathrm{CM}, \mathrm{OP}+\mathrm{CM}$ and $\mathrm{CM}$. N incorporation provides increased fertility of this material, because the $\mathrm{N}$ is released to plant roots in the form of $\mathrm{NO}_{3}{ }^{-}$through various mechanisms of mineralization of SOM.

The vermicomposting process in $\mathrm{FC}+\mathrm{CM}$ pile lasted longer than other treatments. This might be due to the characteristics of the filter cake which contains more lignin that is not easily degraded. In general, the $\mathrm{C} / \mathrm{N}$ ratio determines the ability of the microbial degradation of the wastes, but some organic wastes, such as those derived from plants, despite of having adequate $\mathrm{C} / \mathrm{N}$ ratios may contain a high proportion of lignin, a component that is difficult to degrade. After 105 days, earthworms' activities were no longer observed in 2:1 OP $+\mathrm{CM}$ and $\mathrm{CM}$ piles while their activity was still observed in 3:1 FC $+\mathrm{CM}$ pile. To confirm that the vermicomposts were mature, additional 100 earthworms were added to each container. After 7 days, there were no 
Fig. 2 Changes in $\mathrm{C} / \mathrm{N}$ ratios during the vermicomposting process

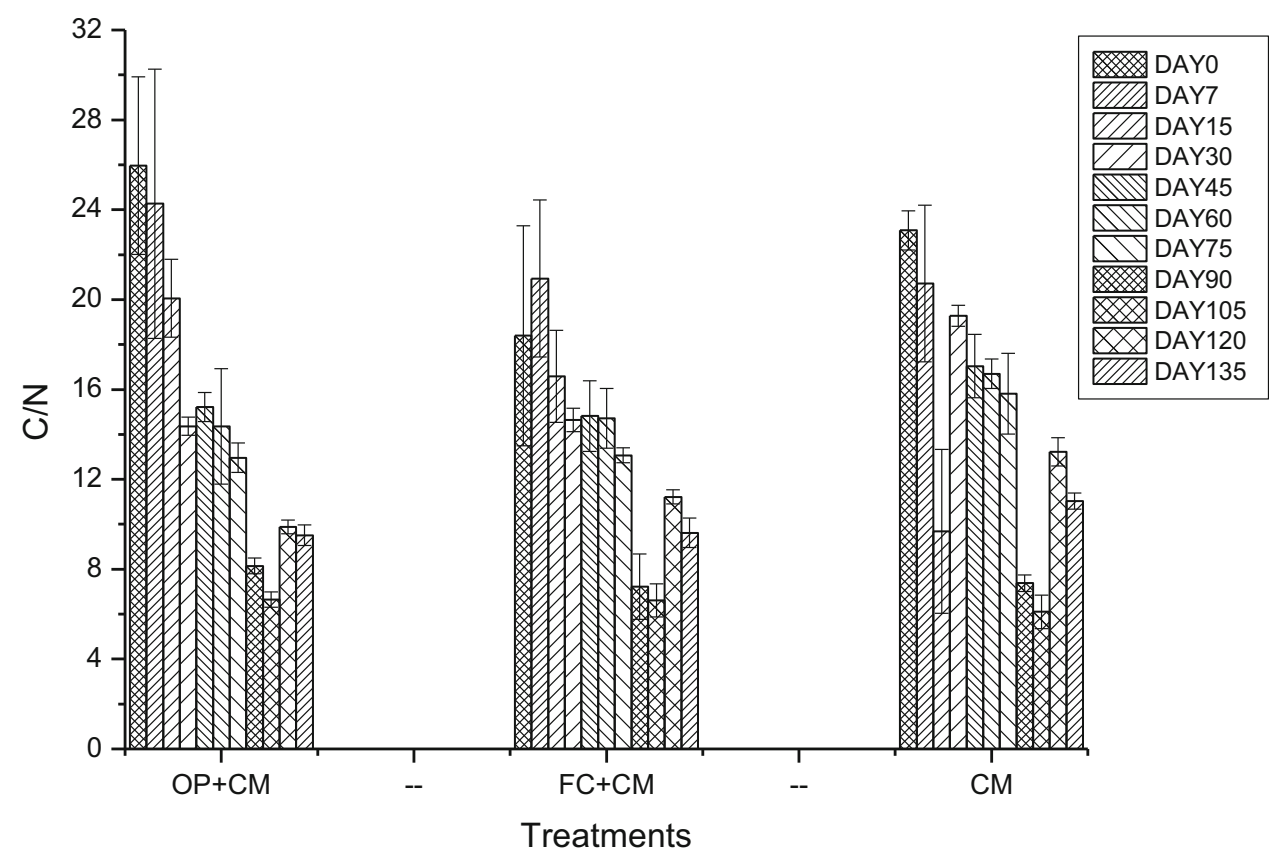

more earthworms in 3:1 FC + CM and CM. Since the humidity was kept constant and the medium slightly basic, this shows that there was no more substrate for the earthworms to feed on. However in FC + CM pile, earthworms' activities ceased after 135 days.

\section{The $\mathbf{N}$ contents of the vermicomposts}

Among the three piles, $2: 1 \mathrm{OP}+\mathrm{CM}$ had the highest $\mathrm{N}$ content at the end of the vermicomposting process (Table 2). The $\mathrm{N}$ content of 3:1 FC $+\mathrm{CM}$ and $\mathrm{CM}$ piles were not significantly different $(p \leq 0.05)$. There was no significant difference in the $\mathrm{C}, \mathrm{H}$ and $\mathrm{S}$ content of all the vermicomposts. Further, while the $\mathrm{C} / \mathrm{N}$ ratios of the vermicomposts from pile 2:1 OP $+\mathrm{CM}$ and 3:1 $\mathrm{FC}+\mathrm{CM}$ were not significantly different, they were significantly lower than that of the CM. This shows that $3: 1 \mathrm{FC}+\mathrm{CM}$ and 2:1 $\mathrm{OP}+\mathrm{CM}$ piles exhibited a higher level of molecular condensation meaning that they exhibited a more advanced stage of humification than CM did (Bernal et al. 1998). Decline in $\mathrm{C} / \mathrm{N}$ ratio was due to higher loss of carbon through microbial respiration in the form of $\mathrm{CO}_{2}$ along with an increase in nitrogen and stabilization of waste by the action of worms (Hait and Tare 2011).

\section{Macro and micronutrient content of the vermicomposts}

In the three different treatments, the $\mathrm{Ca}, \mathrm{Mg}, \mathrm{Mn}$ and $\mathrm{Fe}$ contents significantly $(p \leq 0.05)$ increased at the end of the vermicomposting process when compared with the initial contents (Table 3). While the $\mathrm{K}$ content in 2:1 OP + CM and $\mathrm{CM}$ piles were significantly $(p \leq 0.05)$ higher at the end, the $\mathrm{K}$ content in $3: 1 \mathrm{FC}+\mathrm{CM}$ was not. There was a significant $(p \leq 0.05)$ increase in the $\mathrm{Cu}$ content of $2: 1$ $\mathrm{OP}+\mathrm{CM}$ and $\mathrm{CM}$ while a significant decrease was observed in 3:1 FC + CM. While, the Zn content significantly $(p \leq 0.05)$ increased in $2: 1 \mathrm{OP}+\mathrm{CM}$ and $3: 1$ $\mathrm{FC}+\mathrm{CM}$, there was no significant increase in CM.

There was no significant $(p \leq 0.05)$ increase in the $\mathrm{P}$ contents across the three treatments while the $\mathrm{Cr}$ content in 3:1 FC + CM was close to zero at the end of the vermicomposting unlike in 2:1 $\mathrm{OP}+\mathrm{CM}$ and $\mathrm{CM}$ where no significant difference was observed. This could be attributed to the continuous presence of earthworms in 3:1 $\mathrm{FC}+\mathrm{CM}$ after 105 days. The $\mathrm{Cr}$ level in 3:1 FC + CM at the end of the vermicomposting was close to zero. Bhat et al. (2015) reported an increase of nutrients like N, P and $\mathrm{Na}$ and an increase of metallic elements $\mathrm{Fe}, \mathrm{Zn}$ and $\mathrm{Mn}$ from pre-vermicompost to post-vermicompost of mixtures of bagasse waste from the sugar industry and cattle dung. The authors also observed a significant decrease $(p<0.05)$ in $\mathrm{Cr}$ over initial. According Sangwan et al. (2008) in India, vermicomposting of filter cake in combination with equine manure accelerated mineralization of nutrients and was adequate for growth and reproduction of earthworms.

After 105 days of vermicomposting, earthworms were no longer present in piles 2:1 OP $+\mathrm{CM}$ and $\mathrm{CM}$ suggesting that all the biodegradable material had been decomposed at this time. On the other hand, after 105 days, earthworms were still very active in 3:1 FC + CM pile probably because filter cake is rich in fibre and lignin. 
This suggests that due to the increased duration of decomposition in 3:1 FC $+\mathrm{CM}$ pile, the earthworms were able to bioaccumulate $\mathrm{Cr}$ resulting in decreased values at the end of the process.

At the end of the vermicomposting process, 2:1 $\mathrm{OP}+\mathrm{CM}$ and 3:1 FC + CM had higher contents of macro and micronutrients than CM (Table 4). This might be due to the characteristics of the filter cake and orange peel. The $\mathrm{Ca}, \mathrm{Mg}$ and $\mathrm{K}$ were highest in 2:1 $\mathrm{OP}+\mathrm{CM}$ while the $\mathrm{P}$ content in 2:1 $\mathrm{OP}+\mathrm{CM}$ and $3: 1 \mathrm{FC}+\mathrm{CM}$ were not significantly different but both had significantly $(p \leq 0.05)$ higher $\mathrm{P}$ values than in $\mathrm{CM}(\mathrm{Ca}$ and $\mathrm{Mg}: \quad 2: 1$ $\mathrm{OP}+\mathrm{CM}>3: 1 \quad \mathrm{FC}+\mathrm{CM}>\mathrm{CM}, \quad \mathrm{P}: \quad 2: 1$ $\mathrm{OP}+\mathrm{CM}=3: 1 \mathrm{FC}+\mathrm{CM}>\mathrm{CM})$. Potassium presented the highest level in 2:1 OP $+\mathrm{CM}$ and the lowest in 3:1 $\mathrm{FC}+\mathrm{CM}(2: 1 \mathrm{OP}+\mathrm{CM}>\mathrm{CM}>3: 1 \mathrm{FC}+\mathrm{CM})$.
The results obtained in this study confirm those obtained by Sangwan et al. (2010): it can be said that the costs of agricultural production could be minimized with the use of vermicompost obtained from organic wastes.

\section{Correlations between macro and micronutrients, elemental analysis, $\mathrm{C} / \mathrm{N}, \mathrm{pH}$ and $\mathrm{CEC}$}

The values of CEC at post-vermicomposts were $652.50 \pm 14.36, \quad 490.44 \pm 15.76$ and $596.19 \pm 15.02$ $\mathrm{mmol}_{\mathrm{c}} \mathrm{kg}^{-1}$ for $\mathrm{OP}+\mathrm{CM}$, FC $+\mathrm{CM}$ and $\mathrm{CM}$ piles, respectively. $\mathrm{OP}+\mathrm{CM}$ had significantly highest $\mathrm{CEC}$ $(p \leq 0.05)$. It was observed that the $\mathrm{pH}$ and CEC parameters were strongly positively correlated $(r=0.851 * *)$. This correlation was due to the basic cations which also shows a positive correlation with the CEC (Mg:

Table 3 Macro and micronutrients at the beginning and at the end of vermicomposting process

\begin{tabular}{|c|c|c|c|c|c|c|c|c|c|c|}
\hline Treatments & $\begin{array}{l}\text { Time } \\
\text { (days) }\end{array}$ & $\begin{array}{l}\mathrm{Ca}(\mathrm{mg} \\
\left.\mathrm{kg}^{-1}\right)\end{array}$ & $\begin{array}{l}\mathrm{Mg}(\mathrm{mg} \\
\left.\mathrm{kg}^{-1}\right)\end{array}$ & $\begin{array}{l}\mathrm{P}(\mathrm{mg} \\
\left.\mathrm{kg}^{-1}\right)\end{array}$ & $\begin{array}{l}\mathrm{K}(\mathrm{mg} \\
\left.\mathrm{kg}^{-1}\right)\end{array}$ & $\begin{array}{l}\mathrm{Cu}(\mathrm{mg} \\
\left.\mathrm{kg}^{-1}\right)\end{array}$ & $\begin{array}{l}\mathrm{Mn}(\mathrm{mg} \\
\left.\mathrm{kg}^{-1}\right)\end{array}$ & $\begin{array}{l}\mathrm{Fe}(\mathrm{mg} \\
\left.\mathrm{kg}^{-1}\right)\end{array}$ & $\begin{array}{l}\mathrm{Zn}(\mathrm{mg} \\
\left.\mathrm{kg}^{-1}\right)\end{array}$ & $\begin{array}{l}\mathrm{Cr}(\mathrm{mg} \\
\left.\mathrm{kg}^{-1}\right)\end{array}$ \\
\hline $\mathrm{OP}+\mathrm{CM}$ & 1 & $5702 b$ & $2622 b$ & $5408 \mathrm{a}$ & $16000 \mathrm{~b}$ & $18 b$ & $274 b$ & $9690 \mathrm{~b}$ & $29 b$ & $1534 a$ \\
\hline \multirow[t]{2}{*}{ SD } & & 116.1 & 7.4 & 556.7 & 400.0 & 0.26 & 12.29 & 24.4 & 3.86 & 638.0 \\
\hline & 135 & $18922 \mathrm{a}$ & $3866 a$ & $7173 a$ & $18326 a$ & $19 \mathrm{a}$ & $596 a$ & $14184 a$ & $111 \mathrm{a}$ & $1642 a$ \\
\hline SD & & 210.2 & 13.3 & 612.2 & 102.6 & 0.21 & 15.28 & 10.6 & 4.03 & 120.8 \\
\hline $\mathrm{FC}+\mathrm{CM}$ & 1 & $14602 b$ & $3055 \mathrm{~b}$ & $6585 a$ & $9686 a$ & $35 a$ & $506 b$ & $21410 b$ & $61 b$ & $2073 a$ \\
\hline \multirow[t]{2}{*}{ SD } & & 78.4 & 25.5 & 516.4 & 41.6 & 0.17 & 6.44 & 71.8 & 2.20 & 59.1 \\
\hline & 135 & $16921 \mathrm{a}$ & $3381 \mathrm{a}$ & $8055 a$ & $9486 a$ & $29 b$ & $595 a$ & $23414 a$ & $78 \mathrm{a}$ & $0 \mathrm{~b}$ \\
\hline SD & & 98.3 & 7.4 & 1224.5 & 41.6 & 0.27 & 5.14 & 54.3 & 3.02 & 0.0 \\
\hline $\mathrm{CM}$ & 1 & $8548 b$ & $3251 b$ & $3546 a$ & $12498 b$ & $17 \mathrm{~b}$ & $386 b$ & $12162 b$ & $88 \mathrm{a}$ & $1162 \mathrm{a}$ \\
\hline \multirow[t]{2}{*}{ SD } & & 60.5 & 10.9 & 389.1 & 38.0 & 0.18 & 7.55 & 32.3 & 7.08 & 7.8 \\
\hline & 135 & $9482 a$ & $3347 a$ & $3791 \mathrm{a}$ & $14286 a$ & $20 \mathrm{a}$ & $463 a$ & $13744 a$ & $88 \mathrm{a}$ & $1563 a$ \\
\hline SD & & 23.1 & 3.2 & 169.8 & 41.6 & 0.21 & 15.00 & 41.8 & 1.62 & 304.8 \\
\hline
\end{tabular}

$(\mathrm{OP}+\mathrm{CM})$ Orange peel + Cattle manure; $(\mathrm{FC}+\mathrm{CM})$ Filter cake + Cattle manure; $(\mathrm{CM})$ Cattle manure. Values followed by $(\mathrm{SD})$ standard deviations of three laboratory replicates

a, b Mean values followed by the same letter within the same column are not significantly different at $p<0.05$ by Tukey test

Table 4 Macro and micronutrients at the end of vermicomposting process

\begin{tabular}{llllllllll}
\hline Treatments & $\begin{array}{l}\mathrm{Ca}(\mathrm{mg} \\
\left.\mathrm{kg}^{-1}\right)\end{array}$ & $\begin{array}{l}\mathrm{Mg}(\mathrm{mg} \\
\left.\mathrm{kg}^{-1}\right)\end{array}$ & $\begin{array}{l}\mathrm{P}(\mathrm{mg} \\
\left.\mathrm{kg}^{-1}\right)\end{array}$ & $\begin{array}{l}\mathrm{K}(\mathrm{mg} \\
\left.\mathrm{kg}^{-1}\right)\end{array}$ & $\begin{array}{l}\mathrm{Cu}(\mathrm{mg} \\
\left.\mathrm{kg}^{-1}\right)\end{array}$ & $\begin{array}{l}\mathrm{Mn}(\mathrm{mg} \\
\left.\mathrm{kg}^{-1}\right)\end{array}$ & $\begin{array}{l}\mathrm{Fe}(\mathrm{mg} \\
\left.\mathrm{kg}^{-1}\right)\end{array}$ & $\begin{array}{l}\mathrm{Zn}(\mathrm{mg} \\
\left.\mathrm{kg}^{-1}\right)\end{array}$ \\
\hline $\mathrm{OP}+\mathrm{CM}$ & $18922 \mathrm{a}$ & $3866 \mathrm{a}$ & $7173 \mathrm{a}$ & $18326 \mathrm{a}$ & $18 \mathrm{c}$ & $596 \mathrm{a}$ & $14184 \mathrm{~b}$ & $111 \mathrm{a}$ \\
$\left.\mathrm{kg}^{-1}\right)$
\end{tabular}

$S D$ standard deviation

$(\mathrm{OP}+\mathrm{CM})$ orange peel + cattle manure; $(\mathrm{FC}+\mathrm{CM})$ filter cake + cattle manure; $(\mathrm{CM})$ cattle manure

a, b, c Mean values followed by the same letter within the same column are not significantly different at $p<0.05$ by Tukey test 
$\left.r=0.713^{*}, \mathrm{~K}: r=0.977 * *\right)$. This is so because the basic cations influence the $\mathrm{pH}$, which consequently affects the CEC. The CEC and C contents were also positively correlated $\left(r=0.706^{*}\right)$. This is because the OM, the source of CEC was decomposed by microorganisms during the process of vermicomposting. Likewise, $\mathrm{C}$ and $\mathrm{H}$ showed strong positive correlations $\left(r=0.911^{* *}\right)$, which is related to the evolution of the organic matter humification process, loss of labile $\mathrm{C}$ and the formation of double bonds in the aromatic molecules.

The linear increase and positive correlation between the levels of $C$ and N ( $\left.r=0.941^{* *}\right)$ is related to the mineralization process. At the end of the vermicomposting process, with the death of earthworms and microorganisms, there is a greater availability of nutrients, which initially had been immobilized, as they used them as sources of energy and nutrients. There were positive correlations between $\mathrm{Mg}$ and $\mathrm{K}\left(r=0.806^{* *}\right)$ and $\mathrm{P}$ and $\mathrm{Ca}$ $\left(r=0.867^{* *}\right)$.

\section{Conclusions}

The chemical compositions of the vermicomposting materials had effect on the duration of the process. The $\mathrm{pH}$ and the organic carbon contents were above the minimum recommended values for organic fertilizers. Co-vermicomposting of cattle manures with orange peel or filter cake also resulted in a lower $\mathrm{C} / \mathrm{N}$ ratio. Co-vermicomposting of cattle manure resulted in higher contents of macronutrients, like $\mathrm{N}$ (up to 120 days of vermicomposting). The $\mathrm{N}$ content was below the minimum value but the $\mathrm{C} / \mathrm{N}$ ratio was in the required range. The $\mathrm{C} / \mathrm{N}$ values where lower in $\mathrm{OP}+\mathrm{CM}$ and $\mathrm{FC}+\mathrm{CM}$ piles than in $\mathrm{CM}$ pile. Further, the $\mathrm{N}$ contents of the piles were different, with $\mathrm{OP}+\mathrm{CM}$ having the highest value. The micronutrient values in the matured piles decreased in some piles and increased in others. $\mathrm{Ca}, \mathrm{Mg}, \mathrm{Mn}$ and $\mathrm{Fe}$ contents significantly increased at the post-vermicompost than the prevermicompost for all treatments. The mature $\mathrm{FC}+\mathrm{CM}$ differed very significantly in the content of $\mathrm{Cr}$ due to increased earthworm activity suggesting the bioaccumulation of $\mathrm{Cr}$ by the earthworms. It was observed that vermicomposts from filter cake and orange peel mixed with cattle manure resulted in a better vermicomposts than the ones produced from cattle manure only. Thus, it is recommended that these agricultural wastes can be co-vermicomposted and utilized for sustainable agriculture. The vermicomposts so obtained attend the needs of the Brazilian legislation and the vermicomposting could be introduced as efficient technology to convert wastes of cattle manure with orange peel and filter cake into organic fertilizer. Further studies are also been carried out on the potential of vermicomposted orange peels to reduce pest incidence in soil.

Acknowledgments The authors are grateful to the Brazilian Research Funding Agencies FAPESP (projects 2011/13294-7 and 2011/13918-0) and CNPq (project 306713/2013-9) for their financial support and the Institute of Chemistry of São Carlos, University of São Paulo for the provision of infrastructure.

Authors' contributions All authors, LBFP, IAA, OAO, AVB and MOOR have made adequate effort on all parts of the work necessary for the development of this manuscript according to his/her expertise. All authors read and approved the final manuscript.

\section{Compliance with ethical standards}

Conflict of interest The authors declare that there is no conflict of interest.

Open Access This article is distributed under the terms of the Creative Commons Attribution 4.0 International License (http://crea tivecommons.org/licenses/by/4.0/), which permits unrestricted use, distribution, and reproduction in any medium, provided you give appropriate credit to the original author(s) and the source, provide a link to the Creative Commons license, and indicate if changes were made.

\section{References}

Bernal MP, Paredes SMC, Cegarra J (1998) Maturity and stability parameters of composts prepared with a wide range of organic wastes. Bioresour Technol 63:91-99. doi:10.1016/S09608524(97)00084-9

Bernal MP, Alburquerque JA, Moral R (2009) Composting of animal manures and chemical criteria for compost maturity assessment. A review. Bioresour Technol 100:5444-5453. doi:10.1016/j. biortech.2008.11.027

Bhat SA, Singh J, Vig AP (2015) Potential utilization of bagasse as feed material for earthworm Eisenia fetida and production of vermicompost. Springerplus 4:11. doi:10.1186/s40064-0140780-y

Chefetz B, Hatcher P, Hadar Y, Chen Y (1996) Chemical and biological characterization of organic matter during composting of municipal solid waste. J Environ Qual 25:776-785. doi:10. 2134/jeq1996.00472425002500040018x

Edwards CA, Bohlen PJ (1996) Biology and ecology of earthworms, vol 3. Springer Science \& Business Media, pp 426. ISBN: 0412561603

Fialho LL, Silva WTL, Milori DMBP, Simões ML, Martin-Neto L (2010) Characterization of organic matter from composting of different residues by physicochemical and spectroscopic methods. Bioresour Technol 101:1927-19346. doi:10.1016/j.biortech. 2009.10.039

Hait S, Tare V (2011) Vermistabilization of primary sewage sludge. Bioresour Technol 102:2812-2820. doi:10.1016/j.biortech.2010. 10.031

Huang GF, Wong JWC, Wu QT, Nagar BB (2004) Effect of C/N on composting of pig manure with sawdust. Waste Manag 24:805-813. doi:10.1016/j.wasman.2004.03.011

Huang GF, Wong JWC, Wu QT, Nagar BB (2006) Transformation of organic matter during co-composting of pig manure with sawdust. Bioresour Technol 97:1834-1842. doi:10.1016/j.bior tech.2005.08.024 
Itavo LCV, Santos GT, Jobim CC, Voltolini TV, Faria KP, Ferreira CCB (2000) Composição e digestibilidade aparente da silagem de bagaço de laranja. Revista Brasileira de Zootecnia (In Portuguese) 5:1485-1490. doi:10.1590/S151635982000000500029

Juárez PDA, Fuente JL, Paulín RV (2011) Vermicomposting as a process to stabilize organic waste and sewage sludge as an application for soil. Trop Subtrop Agroecosyst 14:949-963. doi:10.1007/s11356-011-0606-1

Morelli JL (2004) Compostagem de resíduos produzidos pelas usinas de cana-de-açúcar. In: SIMPÓSIO SOBRE COMPOSTAGEM: SICOM, 1, 2004, Botucatu. Anais. Botucatu: UNESP, CD-ROM (In Portuguese)

Pramanik P, Ghosh GK, Ghosal PK, Banik P (2007) Changes in organic: C, N, P and K and enzyme activities in vermicompost of biodegradable organic wastes under liming and microbial inoculants. Bioresour Technol 98:2485-2494. doi:10.1016/j. biortech.2006.09.017

Provenzano MR, Oliveira SC, Silva MRS, Senesi N (2001) Assessment of maturity degree of composts from domestic solid wastes by fluorescence and Fourier transform infrared spectroscopies. J Agric Food Chem 49:5874-5879. doi:10.1021/jf0106796

Rezende MOO, Dores-Silva PR, Silva MD, Zozolotto TCB, Landgraf MD (2014) Understanding the vermicompost process in sewage sludge: a Humic fraction study. Int J Agric For 4(2):94-99. doi:10.5923/j.ijaf.20140402.08

Rodella AA, Alcarde JC (1994) Assessment of organic materials used as fertilizers (in Portuguese). Sci Agric 51(3):556-562

Ros M, García C, Hernández T (2006) A full-scale study of treatment of pig slurry by composting: Kinetic changes in chemical and microbial properties. Waste Manag 26:1108-1118. doi:10.1016/ j.wasman.2005.08.008

Sangwan P, Kaushik CP, Garg VK (2008) Feasibility of utilization of horse dung spiked filter cake in vermicomposters using exotic earthworm Eisenia foetida. Bioresour Technol 99(7):2442-2448. doi:10.1016/j.biortech.2007.04.061

Sangwan P, Kaushik CP, Garg VK (2010) Growth and yield response of marigold to potting media containing vermicompost produced from different wastes. Environmentalist 30:123-130. doi:10. 1007/s10669-009-9251-3

SAS Institute (2004) The SAS system for Windows. SAS Inst., Cary Suthar S (2012) Earthworm production in cattle dung vermicomposting system under different stocking density loads. Environ Sci Poll Res Int 19(3):748-755. doi:10.1007/s11356-011-0606-1 